\title{
Effects of Prepartally Supplements of Vitamins and Trace Elements on Total Antioxidant and Oxidant Status and Udder Health Parameters on Day 14 Postpartum in Holstein-Friesian Cows
}

\author{
Serdal KURT ${ }^{1}$, Seçkin SALAR ${ }^{1}$, Şükrü KÜPLÜLÜ¹, Ayhan BAŞTAN* \\ ${ }^{1}$ Ankara University, Faculty of Veterinary Medicine, Department of Obstetrics and Gynecology, 06110, Ankara, Turkey
}

\begin{abstract}
The aim of this study was to evaluate the effects of prepartally injections of antioxidants on total antioxidant status (TAS), total oxidant status (TOS) and udder health parameters on day 14 postpartum in Holstein-Friesian cows. Sixty-eight multiparous cows were divided into treatment (TRE; $n=33$ ) and control (CON; $n=35)$ groups. Injections of vitamins (A, D and $\mathrm{E}$ ) and trace elements ( $\mathrm{Se}, \mathrm{Cu}, \mathrm{Zn}$ and $\mathrm{Mn}$ ) were administered intramuscularly to cows into the TRE group on $21 \pm 5$ and $10 \pm 5$ days prepartum. Blood and milk samples were collected to evaluate beta-hydroxybutyric acid (BHBA), TAS, TOS and udder health (somatic cell count (SCC), total bacterial count (individual bacteria count (IBC) and colony formation unit (CFU)). TAS levels were higher in the TRE group than the CON group. And TOS levels were lower in the TRE group than the CON group $(\mathrm{P}<0.001)$. Cows in the TRE group had lower SCC than the cows in the CON group $(\mathrm{p}=0.042)$. In conclusion, prepartally supplements of antioxidants were effectively reduced levels of serum TOS and SCC and increased levels of serum TAS. But, it was detected that it did not affect on IBC and CFU levels.
\end{abstract}

Keywords: Antioxidant, cows, somatic cell count, total bacteria count, udder health.

Holstein-Friesian İneklerde Prepartal Vitamin ve İz Element Takviyelerinin Postpartum 14. Günde Toplam Antioksidan ve Oksidan Durumları ve Meme Sağlığı Parametreleri Üzerine Etkileri

ÖZ

Bu çalışmanın amacı, Holstein-Friesian 1 rkı ineklerde prepartal vitamin ve iz element enjeksiyonlarının postpartum 14. günde toplam antioksidan ve oksidan seviyeleri (TOS ve TAS) ile meme sağlğ̆1 parametreleri üzerine etkilerinin değerlendirilmesiydi. Altmıs sekiz multipar inek tedavi (TED; $n=33)$ ve kontrol $(K O N ; n=35)$ grubu olarak ikiye ayrild. TED grubundaki ineklere prepartum $21 \pm 5$ ve $10 \pm 5$ günlerde intramuskuler vitamin (A, D, E) ve iz element ( $\mathrm{Cu}, \mathrm{Zn}, \mathrm{Se}, \mathrm{Mn})$ enjeksiyonları yapıldı. Beta hidroksi bütirik asit (BHBA), TOS ve TAS ile meme sağlı̆ı̆nı (somatik hücre sayısı (SHS), toplam bakteri sayısı (bireysel bakteri sayısı (BBS) ve koloni oluşturan birim (KOB)) değerlendirmek için kan ve süt örnekleri toplandı. TAS seviyesi kontrol grubuna göre tedavi grubunda daha yüksek bulunurken TOS seviyesi daha düşük bulundu. Tedavi grubundaki ineklerin SHS’leri, kontrol grubundakilerden daha düşüktü $(\mathrm{p}=0.042)$. Sonuç olarak, prepartal antioksidan takviyelerinin serum TOS ve süt SHS seviyelerini etkili bir şekilde düşürdüğü ve serum TAS seviyesini arttırdığı görüldü. Ancak BBS ve KOB seviyelerine etki etmediği tespit edildi.

Anahtar Kelimeler: Antioksidan, inek, meme sağlı̆ı, somatik hücre sayısı, toplam bakteri sayısı.

To cite this article: Kurt S. Salar S. Küplülü S. Bastan A. Effects of Prepartally Supplements of Vitamins and Trace Elements on Total Antioxidant and Oxidant Status and Udder Health Parameters on Day 14 Postpartum in Holstein-Friesian Cows. Kocatepe Vet J. (2019) 12(3):322-328 


\section{INTRODUCTION}

Vitamins and trace elements are antioxidant substances and they play a role in the body's antioxidant defense system (Sen and Chakraborty 2011). Antioxidants are defined as substances that inhibit oxidative damage (Abuelo et al. 2015) and are obtained in two different ways as endogenous (enzymatic and non-enzymatic) and exogenous (Sen and Chakraborty 2011). The most common antioxidant substances which exogenously obtained are vitamin $\mathrm{A}$, vitamin $\mathrm{E}$, vitamin $\mathrm{D}$, vitamin $\mathrm{C}$, selenium (Se), copper $(\mathrm{Cu})$, manganese $(\mathrm{Mn})$ and zinc ( $\mathrm{Zn})$ (Mavangira and Sordillo 2018). Exogenous antioxidant substances have also clinical importance because they are used in the structure of endogenous antioxidants (superoxide dismutase (SOD), glutathione peroxidase (GPX) and catalase (CAT)) (Sen and Chakraborty 2011). Oxidant substances (free radicals) generally classified into two categories as reactive oxygen species (ROS) and reactive nitrogen species (RNS) (Lykkesfeldt and Svendsen 2007). They are produced as natural by-products during the conversion of foods into a form of ATP using $\mathrm{O}_{2}$ in the mitochondria (Mavangira and Sordillo 2018). But, ROS (such as RO, RCOO, $\mathrm{H}_{2} \mathrm{O}_{2}, \mathrm{HO}_{-}, \mathrm{HO}_{2}, \mathrm{O}_{2}{ }^{-}$, $\left.\mathrm{O}_{3}\right)$ are the most abundant oxidant substances in biological systems (Puppel et al. 2015). ROS are reduced to a new molecule such as $\mathrm{H}_{2} \mathrm{O}$ by antioxidant substances, or they are enzymatically repaired by antioxidants. ROS are reduced to a new molecule such as $\mathrm{H}_{2} \mathrm{O}$ or they are enzymatically repaired by antioxidants (Sordillo and Aitken 2009). But, when the production of free radicals exceeds the antioxidants defense capacity, oxidative stress occurs (Batistel et al. 2018). It has been reported that oxidative stress impairs cells' structures (especially immune cells) by damaging their macro components such as DNA, lipid and protein (Kuhn et al. 2018). In addition, it is known that excessive oxidative stress can cause pathologic disorders of tissue and organ. These pathologic disorders begin with function, activity and immunological deficits particularly in the heart, skeletal muscle, liver and blood cells that require high energy (Puppel et al. 2015). The periparturient periods are critical for oxidative stress in dairy cows. The use of $\mathrm{O}_{2}$ during the transition period in the cows increases due to the acceleration of metabolic activities (Castillo et al. 2005). Moreover, the cows enter a negative energy balance (NEB) because of increased metabolic demands in this period (Abuelo et al. 2015). NEB induces more lipolysis that gives rise to increased ROS production and results in enhanced blood non-esterified fatty acids (NEFA) (Song et al. 2014) and betahydroxybutyric acid (BHBA) concentrations (Wankhade et al. 2017). Therefore, the oxidant concentration significantly increases while the total antioxidant capacity decreases with antioxidant overuse during this period (Mavangira and Sordillo 2018). It was reported that inadequate levels of antioxidants result in leukocyte dysfunction and then health problems are enhanced (Sordillo and Aitken 2009, Mavangira and Sordillo 2018). Furthermore, it is known that udder health is affected negatively in the case of oxidative stress (Abuelo et al. 2015).

For these reasons, antioxidant administrations have clinical importance in the periparturient period (Spears and Weiss 2008). Therefore, this study was aimed to evaluate the effect of prepartally injections of some vitamins and trace elements on total antioxidant status (TAS), total oxidant status (TOS) of serum samples and udder health parameters involving in SCC and total bacteria count (individual bacteria count (IBC) and colony formation unit $(\mathrm{CFU}))$ on day 14 postpartum in Holstein-Friesian cows.

\section{MATERIAL and METHODS}

\section{Animals, Housing, Diets and Management}

Sixt-yeight pregnant multiparous Holstein-Friesian dairy cows were used in this study. The farms were visited before starting the study and the cows used were selected from the Holstein-Friesian cows which in the dry period and without any clinical disease, then they were divided into treatment (TRE; $n=33$ ) and control $(\mathrm{CON} ; \mathrm{n}=35)$ groups by the randomized grouping method. The cows were managed in freestall barns, were fed according to their individual needs with a total mix ration (TMR) and had free access to water. Chemical analysis of TMR into faroff, close up and fresh periods were done according to the AOAC method (Joel, 1990; Table 1). Milk yield of the previous lactation (305-d) and lactation number of the cows in both groups were similar ( $>0.05$; Table 2). The cows were milked with an automatic milking system twice daily. The herds had periodic systematic vaccination and controlled health monitoring programs.

\section{Experimental Design}

This study was conducted between December 2018 and March 2019. In this study, $8 \mathrm{ml}$ of solution (Ademin ${ }^{\circledR}$, Ceva) containing vitamins $\mathrm{A}, \mathrm{D}$ and $\mathrm{E}$ (500,000 I.U. of vitamin A, 75,000 I.U. of vitamin D and $50 \mathrm{mg}$ of vitamin $\mathrm{E}$ per $\mathrm{ml}$ ) and $10 \mathrm{ml}$ of solution (Activate ${ }^{\circledR}$, Alke) containing $\mathrm{Se}, \mathrm{Cu}, \mathrm{Zn}$ and $\mathrm{Mn}$ trace elements $(2.5 \mathrm{mg}$ of copper gluconate, $1.25 \mathrm{mg}$ of sodium selenite, $5 \mathrm{mg}$ of manganese gluconate, $5 \mathrm{mg}$ of zinc gluconate per $\mathrm{ml}$ ) were administered intramuscularly (im) using a $18-G$ cannula to each cow into the TRE group on $21 \pm 5$ and $10 \pm 5$ days before expected parturition (280 days) (Figure 1). In the CON group, it was performed the same amounts of saline injections as a placebo to each cow. 


\section{Sampling and Laboratory Analysis}

Blood samples $(9 \mathrm{ml})$ were collected from the coccygeal vein into vacutainer tubes (Hema \& Tube $^{\circledR}$ ) containing clot activator at postpartum $14^{\text {th }}$ days. The blood samples were centrifuged (Nüve, NF 200 centrifuge $\left.^{\circledR}\right)$ at $1.500 \mathrm{~g}$ and $4^{\circ} \mathrm{C}$ for $10 \mathrm{~min}$ within $1 \mathrm{~h}$ after the sampling and serum were stored at $-20^{\circ} \mathrm{C}$ until analyses. Milk samples $(10 \mathrm{ml})$ were collected to a sterile falcon equally from 4 lobes of udder on 14th days postpartum. The samples were kept chilled on ice-packs immediately during collection and were transported to the laboratory $+4^{\circ} \mathrm{C}$ for analyses within 8 hours. TOS and TAS were measured using autoanalyzer (Erba XL $600^{\circledR}$ ) and commercial kits (LOT: OK18104O and OK18095A respectively, Rel Assay Diagnostics, Gaziantep). Milk SCC and total bacterial count (IBC and CFU) was determined by an automated fluorescent microscopic somatic cell counter (Bentley IBC-M ${ }^{\circledR}$; Bentley Instruments Inc., Chaska, MN, USA). And also, BHBA levels were measured instantly using a hand-held meter (Vet TD4235, Hasvet ${ }^{\circledR}$, Turkey) $\beta$-ketone monitoring system and commercial kits (LOT: WK18D923-B0E) on day 14th postpartum.

\section{Statistical Analysis}

Kolmogorov-Smirnov and Levene test were used for normality and homogeneity of variance of data, respectively. When data were not distributed normally, logarithmic conversations $(\log 10)$ were done. Independent sample t-test was used to compare means of all variables. Results were presented as the mean \pm standard error of the mean $(\bar{x} \pm$ SEM). SPSS 14.01 (SPSS Inc., Chicago, Illinois, USA; License No: 98692604) software package program was used for all statistical analyses. $\mathrm{P}<0.05$ was considered as significant.

\section{RESULT and DISCUSSION}

Beta-hydroxybutyric acid levels were found similar in the TRE $(0.66 \pm 0.08 \mathrm{mmol} / \mathrm{L})$ and CON $(0.88 \pm 0.19$ $\mathrm{mmol} / \mathrm{L})$ groups $(\mathrm{p}=0.186)$. Results from this study showed that prepartally supplements of vitamins and trace elements were effectively decreased levels of TOS $(p<0.001)$ and were effectively increased levels of TAS ( $\mathrm{p}=0.036$; Table 3). And also, it was detected that it can be used to reduce the incidence and damage of oxidative stress in dairy cows.

The SCC level in the TRE group (559.94 \pm 199.88 cells $/ \mathrm{ml}$ ) had lower than the CON group $(1173.03 \pm 321.32$ cells $/ \mathrm{ml})(\mathrm{p}=0.042)$. However, IBC level in the TRE group $(771860.82 \pm 324756.90)$ was similar compare to the $\mathrm{CON}$ group (658889.71 $\pm 289864.33 \mathrm{IBC} / \mathrm{ml})$. Also, CFU levels were found similar the TRE group (228.58 \pm 93.38$)$ and the CON group $(186.17 \pm 80.19 \mathrm{CFU} / \mathrm{ml})$ ( $>0.05$; Table 4).
Free radicals play an important role in the host immune system and low levels of ROS are required for antibacterial activities of neutrophils (Andrei et al. 2011). It was reported that when more than normal of ROS is produced if there are not enough antioxidant substances in the body, pathologies of organ and tissue occur as a consequence of oxidative damage (Lykkesfeldt and Svendsen 2007). Dairy cows are vulnerable to oxidative stress, particularly during the transition period. Some researchers described that the production of ROS and the use of antioxidants substances are importantly increased due to increased metabolic activity in the periparturient period (Spears and Weiss 2008, Sordillo and Aitken 2009). Moreover, Song et al., (2014) reported that ROS generation increases due to increased lipolysis as a consequence of NEB during the transition period. Blood concentration of BHBA is directly proportional to NEB (Barletta et al. 2017). In our study, however, BHBA levels were found similar in the TRE and CON group ( $p=0.186)$. Therefore, this result showed that the effect of lipolysis on the production of ROS was homogenous in both groups. Antioxidant supplementation has improving effects on the health and performance of dairy cows (Spears and Weiss 2008, Abuelo et al. 2016). In other words, antioxidant administrations can be used to diminish the destructive effects of excessive ROS generation (Abuelo et al. 2016). For this reason, antioxidant supplementation can be performed by the addition of vitamins, minerals and trace elements to the diet of the cows, especially in the form of premixes added to the TMR. Besides, it can be done with commercial vitamins and trace element injections for facilitating the supplementation without requiring particular management (Abuelo et al. 2015). Many researchers have reported that when trace elements are used as feed additives in organic form, more positive results are obtained than other approaches (Ballantine et al. 2002, Andrieu 2008, DeFrain et al. 2009). It is stated that this is due to interactions in the gastrointestinal tract (Gressley 2009). Previous studies showed that positive results were obtained with parenteral supplementation of commercial formulations of vitamins and trace elements with antioxidant properties in dairy cows. However, in order to compare the effectiveness of administration of the organic or inorganic forms as well as of feed additives or injections, more detailed studies on antioxidant supplementation methods should be carried out especially during the transition period in which changes in the gastrointestinal environment and $\mathrm{pH}$ due to ration changes. Although it is suggested that TAS and TOS can be effective in monitoring the feeding status (Mandebvu et al. 2003) and some diseases in dairy cows (Atakisi et al. 2010), the results may vary depending on the measurement method (Andrei et al. 2016) and the feeding differences (Mandebvu et al. 2003). TAS represents the sum of all the antioxidants present in serum (Castillo et al. 2005, 
Lykkesfeldt and Svendsen 2007). TAS levels significantly decrease during early lactation and dairy cows have a low antioxidant defense in this period (Gong and Xiao 2016). It was reported that prepartum antioxidant administrations increase serum TAS in cows (Omur et al. 2016). Omur et al. (2016) reported that administration of vitamin (A, D and $\mathrm{E})$ and trace element ( $\mathrm{Se}, \mathrm{Cu}, \mathrm{Mn}, \mathrm{Zn}$ ) combinations in three weeks before parturition caused an increase in the total antioxidant capacity and a decrease in the total oxidant capacity in three weeks after parturition. In our study, it was found that administrations of vitamins and trace elements on $21 \pm 5$ and $10 \pm 5$ days before parturition were increased the level of TAS $(\mathrm{P}=0.036)$ while decreasing TOS $(\mathrm{P}<0.001)$ level in two weeks after parturition. Oxidative stress is associated with many health disorders and it may cause impairment of udder health which has economic importance in dairy cows (Turk et al. 2017). It was reported that milk SCC reflects udder health and administration of trace elements parenterally (Se, $\mathrm{Cu}, \mathrm{Zn}$ and $\mathrm{Mn}$ ) improve udder health by reducing SCC in dairy cows. (Abuelo et al. 2015). Yang and Li (2015) reported that supplements of some antioxidant (vitamin A, B, C, E and $\beta$-carotene, Se, $\mathrm{Zn}$ and $\mathrm{Cu}$ ) successfully prevent mastitis. Antioxidant administrations increase the bactericidal and phagocytic activity of immune cells and decrease the SCC rate in dairy cows (Yang and Li 2015). It was stated that injections of vitamin $\mathrm{E}$ about 10 and $5 \mathrm{~d}$ before parturition increased neutrophil $\alpha$-tocopherol concentrations in the periparturient period in cows. In addition, it was also reported that vitamin $\mathrm{E}$ and $\mathrm{Se}$ supplementations improve the bactericidal activity of neutrophils and at the same time, Se administration reduce the bacterial CFU in milk (Hogan et al. 1993).
The administration of combinations or separately of vitamins and trace elements has significant effects synergistically on the improvement of udder health (Yang and Li 2015). In our study, it was determined that prepartally supplementation of vitamins and trace elements decreased SCC (47.73\%) significantly in the TRE group compared to the CON group $(\mathrm{P}=0.042)$ and therefore it had a positive effect on udder health. In contrast to similar studies, however, no significant difference was found in levels of milk IBC and CFU $(p>0.05)$ when compared the TRE group to the CON group. The reason for this situation is thought that the dominant type of bacteria responsible for mastitis is Staphylococcus aureus. Reduction in the SCC may be interpreted as a decrease in the severity of inflammation due to intramammary infection rather than bacteriological recovery. Although antioxidant supplementations can improve the function of immune system cells, the bacteriological recovery rate is insufficient because bacteria such as $S$. aureus have the ability to escape from immune system cells and even the ability living intracellularly in macrophages and in alveolar cells (Batistel et al. 2018). In addition, the SCC level according to the bacterial species is significantly different. Therefore, the SCC threshold value has a different level of specificity and sensitivity depending on the type of bacteria (Petzer et al. 2017). Similarly, SCC is an effective indicator in determining the presence of intramammary infection, but it is not sufficient to the evaluation of the difference in mastitis pathogen because correlation level of differences between SCC and total bacterial count (IBC and CFU) varies according to the type of pathogen (Junior et al. 2012).

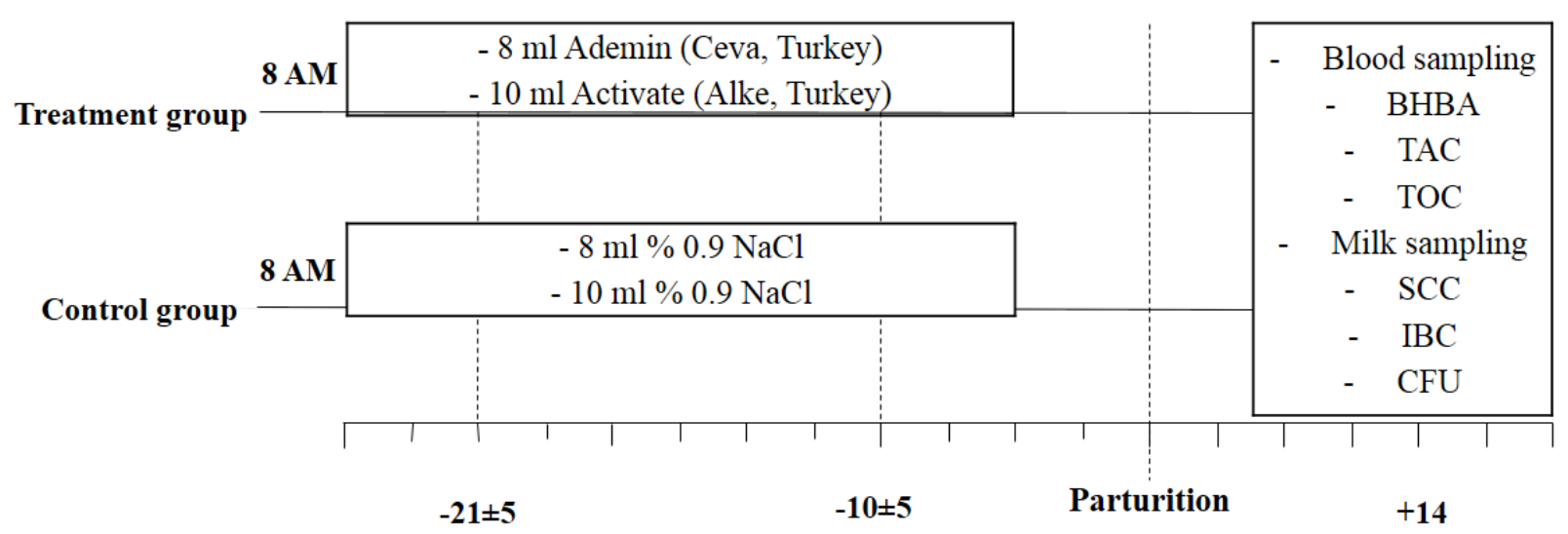

Figure 1. Prepartum supplements of vitamins and trace elements and parameter measurement on day 14th postpartum in Holstein dairy cows 
Table 1. Ration content (100\% dry matter basis) of cows in two groups in the dry period (Far-off and Close-up) and fresh period

\begin{tabular}{lccc} 
& Far-off & Close-up & Fresh \\
\cline { 2 - 4 } Crude Protein & 14,29 & 16,53 & 16,48 \\
Crude Ash & 6,76 & 6,68 & 7,04 \\
Fiber & 20,46 & 21,20 & 20,93 \\
Fat & 2,90 & 2,34 & 2,59 \\
Starch & 6,76 & 20,37 & 22,78 \\
Nel & 1495,56 & 1508,93 & 1513,39 \\
Ndf & 38,80 & 38,23 & 36,85 \\
ADF & 20,27 & 18,03 & 20 \\
ADL & 5,79 & 5,84 & 5,93 \\
MEX1 & 2540,42 & 2553,62 & 2564,54 \\
\hline
\end{tabular}

Nel: Dietary value of net energy, Ndf: Neutral detergent fiber, ADF: Acid detergent fiber, ADL: Acid detergent insoluble lignin, MEX1: Energy that can be metabolized.

Table 2. Comparison of descriptive data in both groups

\begin{tabular}{cccc}
\hline & Treatment & Control & p \\
& $(\mathrm{n}: 33 ;$ Mean \pm SEM) & $(\mathrm{n}: 35 ;$ Mean \pm SEM) & \\
\cline { 2 - 4 } Milk yield of the previous lactation (L) & $10374.88 \pm 452.13$ & $11374.26 \pm 582.92$ & 0.184 \\
Number of lactation & $3 \pm 0.21$ & $3.51 \pm 0.21$ & 0.097 \\
\hline
\end{tabular}

Table 3. Comparison of the levels of total oxidant status (TOS) and total antioxidant status (TAS) of serum samples in both groups

\begin{tabular}{cccc}
\hline & Treatment & Control & p \\
\cline { 2 - 4 }$(\mathrm{n}: 33 ;$ Mean \pm SEM $)$ & $(\mathrm{n}: 35 ;$ Mean \pm SEM $)$ & \\
TOS $(\boldsymbol{\mu m o l} / \mathbf{L})$ & $9.65 \pm 0.51$ & $13.6 \pm 0.46$ & $<0.001$ \\
TAS $(\mathrm{mmol} / \mathrm{L})$ & $2.46 \pm 0.02$ & $2.39 \pm 0.02$ & 0.036 \\
\hline
\end{tabular}

Table 4. Comparison of udder health parameters in both groups

\begin{tabular}{cccc}
\hline & Treatment & Control & P \\
& $(\mathrm{n}: 33 ;$ Mean \pm SEM $)$ & $(\mathrm{n}: 35 ;$ Mean \pm SEM $)$ & \\
\hline SCC $\left(\mathbf{x} \mathbf{1 0}^{\mathbf{3}}\right.$ cells/ml) & $559.94 \pm 199.88$ & $1173.03 \pm 321.32$ & 0.042 \\
IBC $(\mathbf{i b c} / \mathbf{m l})$ & $771860.82 \pm 324756.90$ & $658889.71 \pm 289864.33$ & 0.554 \\
CFU $(\mathbf{c f u} / \mathbf{m l})$ & $228.58 \pm 93.38$ & $186.17 \pm 80.19$ & 0.674 \\
\hline
\end{tabular}

SCC: Somatic cell count, IBC: Individual bacteria count, CFU: Colony formation unit.

\section{CONCLUSION}

Cows supplemented parentally with vitamin (A, D and E) and trace elements (Se, $\mathrm{Zn}, \mathrm{Cu}$ and $\mathrm{Mn}$ ) before parturition showed improved udder health, TAS and TOS levels in the second weeks of lactation, thus decreasing effects of oxidative stress on health in dairy cows. But, milk bacteria count was not affected by antioxidant administrations. Further studies are needed to investigate in more detail the effects of antioxidant administrations on milk bacterial populations. 


\section{ACKNOWLEDGEMENT}

Ankara University-Scientific Research Projects (BAP)

Coordinator project number: 18L0239022.

This article was produced from the Ph.D. thesis titled Investigation Effect of Prepartum Antioxidant Administration on Oxidative Stress Energy Metabolism and Colostrum Quality in Cows' which belongs to Serdal Kurt.

This article was presented as abstract in 1st International Congress of Farm Animal Medicine

Ethical Committee: 2019-7-79

\section{REFERENCES}

Abuelo A, Hernandez J, Benedito JL, Castillo C. The importance of the oxidative status of dairy cattle in the periparturient period: revisiting antioxidant supplementation. J Anim Physiol Anim Nutr. 2015; 99(6): 1003-1016.

Abuelo A, Alves-Nores V, Hernandez J, Muino R, Benedito JL, Castillo C. Effect of parenteral antioxidant supplementation during the dry period on postpartum glucose tolerance in dairy cows. J vet Intern Med. 2016; 30(3): 892-898.

Andrei S, Matei S, Fit N, Cernea C, Ciupe S, Bogdan S, Groza IS. Glutathione peroxidase activity and its relationship with somatic cell count, number of colony forming units and protein content in subclinical mastitis cows milk. Rom Biotech Lett. 2011; 16(3): 6209-6217.

Andrei S, Matei S, Rugină D, Bogdan L, Ştefanuț C. Interrelationships between the content of oxidative markers, antioxidative status, and somatic cell count in cow’s milk. J Anim Sci. 2016; 61(9): 407-413.

Andrieu S. Is there a role for organic trace element supplements in transition cow health? Vet J. 2008; 176(1): 77-83.

Atakisi O, Oral H, Atakisi E, Merhan O, Pancarci SM, Ozcan A, Kaya S. Subclinical mastitis causes alterations in nitric oxide, total oxidant and antioxidant capacity in cow milk. J Vet Res. 2010; 89(1): 10-13.

Ballantine HT, Socha MT, Tomlinson DAD, Johnson AB, Fielding AS, Shearer JK, Van Amstel SR. Effects of feeding complexed zinc, manganese, copper, and cobalt to late gestation and lactating dairy cows on claw integrity, reproduction, and lactation performance. PAS. 2002; 18(3): 211-218.

Barletta RV, Maturana Filho M, Carvalho PD, Del Valle TA, Netto AS, Renno FP, Sartori R. Association of changes among body condition score during the transition period with NEFA and BHBA concentrations, milk production, fertility, and health of Holstein cows. Theriogenology. 2017; 104(1): 30-36

Batistel F, Arroyo JM, Garces CIM, Trevisi E, Parys C, Ballou MA, Loor JJ. Ethyl-cellulose rumen-protected methionine alleviates inflammation and oxidative stress and improves neutrophil function during the periparturient period and early lactation in Holstein dairy cows. J Dairy Sci. 2018; 101(1): 480-490.

Castillo C, Hernandez J, Bravo A, Lopez-Alonso M, Pereira V, Benedito JL. Oxidative status during late pregnancy and early lactation in dairy cows. Vet J. 2005; 169(2): 286292.
DeFrain JM, Socha MT, Tomlinson DJ, Kluth D. Effect of complexed trace minerals on the performance of lactating dairy cows on a commercial dairy. PAS. 2009; 25(6): 709715.

Gong J, Xiao M. Selenium and antioxidant status in dairy cows at different stages of lactation. Biol Trace Elem Res. 2016; 171(1): 89-93.

Gressley TF. Zinc, copper, manganese, and selenium in dairy cattle rations, In: Proceedings of the Mid-Atlantic Nutrition Conference, Ed; Zimmermann NG, 7th Ed., College Park, USA. 2009; pp. 56-71.

Hogan JS, Weiss WP, Smith KL. Role of vitamin E and selenium in host defense against mastitis. J Dairy Sci. 1993; 76(9): 2795-2803.

Joel MP. Animal feed, In: Official Methods of Analysis of The Associations of Official Analytic Chemists, Ed; Kenneth H, 15 th Ed., Arlington, USA. 1990; pp. 69-88.

Junior L, Ferreira JE, Lange CC, Brito MAVP, Santos FR, Silva MAS, Souza GND. Relationship between total bacteria counts and somatic cell counts from mammary quarters infected by mastitis pathogens. Crenc Rural. 2012; 42(4): 691-696.

Kuhn MJ, Mavangira V, Gandy JC, Sordillo LM. Production of 15-F2t-isoprostane as an assessment of oxidative stress in dairy cows at different stages of lactation. J Dairy Sci. 2018; 101(10): 9287-9295.

Lykkesfeldt J, Svendsen O. Oxidants and antioxidants in disease: oxidative stress in farm animals. Vet J. 2007; 173(3): 502-511.

Mandebvu P, Castillo JB, Steckley DJ, Evans E. Total antioxidant capacity: A tool for evaluating the nutritional status of dairy heifers and cows. Can Anim Sci. 2003; 83(3): 605-608.

Mavangira V, Sordillo LM. Role of lipid mediators in the regulation of oxidative stress and inflammatory responses in dairy cattle. Research in veterinary science. 2018;116(1): 4-14.

Omur A, Kirbas A, Aksu E, Kandemir F, Dorman E, Kaynar O, Ucar O. Effects of antioxidant vitamins (A, D, E) and trace elements $(\mathrm{Cu}, \mathrm{Mn}, \mathrm{Se}, \mathrm{Zn})$ on some metabolic and reproductive profiles in dairy cows during transition period. Pol J Vet Sci. 2016; 19(4): 697-706.

Petzer IM, Karzis J, Donkin EF, Webb EC, Etter E. Validity of somatic cell count as indicator of pathogen-specific intramammary infections. F S Afr Vet Assoc. 2017; 88(1): $1-10$.

Puppel K, Kapusta A, Kuczynska B. The etiology of oxidative stress in the various species of animals, a review. J Sci Food Agric. 2015; 95(11): 2179-2184.

Sen S, Chakraborty R. The role of antioxidants in human health. Oxidative stress: diagnostics, prevention, and therapy. JACS 2011; 1083(1): 1-37.

Song Y, Li X, Li Y, Li N, Shi X, Ding H, Wang Z. Nonesterified fatty acids activate the ROS-p38-p53/Nrf2 signaling pathway to induce bovine hepatocyte apoptosis in vitro. Apoptosis. 2014; 19(6): 984-997.

Sordillo LM, Aitken SL. Impact of oxidative stress on the health and immune function of dairy cattle. Vet Immunol Immunop. 2009; 128(1): 104-109.

Spears J W, Weiss WP. Role of antioxidants and trace elements in health and immunity of transition dairy cows. Vet J. 2008; 176(1): 70-76.

Turk R, Koledic M, Macesic N, Benic M, Dobranic V, Duricic D, Samardzija M. The role of oxidative stress 
and inflammatory response in the pathogenesis of mastitis in dairy cows. MLJEAU. 2017; 67(2): 91-101

Wankhade PR, Manimaran A, Kumaresan A, Jeyakumar S, Ramesha KP, Sejian V, Varghese MR. Metabolic and immunological changes in transition dairy cows: A review. Vet World. 2017; 10(11): 1367.

Yang FL, Li XS. Role of antioxidant vitamins and trace elements in mastitis in dairy cows. J Adv. 2015; 2(1): 1-9. 